\title{
Assessing the relevance of nucleic acid content as an indicator of marine bacterial activity
}

\author{
Xosé Anxelu G. Morán ${ }^{1, *}$, Antonio Bode ${ }^{2}$, Luis Ángel Suárez ${ }^{1}$, Enrique Nogueira ${ }^{1}$ \\ ${ }^{1}$ Centro Oceanográfico de Xixón, IEO, Camín de L'Arbeyal, s/n, 33212 Xixón, Spain \\ ${ }^{2}$ Centro Oceanográfico de A Coruña, IEO, Muelle de Ánimas, s/n, Apdo. 130, 15080 A Coruña, Spain
}

\begin{abstract}
Current flow cytometry techniques allow the rapid estimation of the abundance of 2 distinct groups of heterotrophic bacteria, characterized by their relative nucleic acid content. High nucleic acid (HNA) bacteria are, at least in coastal environments, usually regarded as more active than the low nucleic acid (LNA) group. We tested the effects of substrate supply and bacterial cell size on the relationship between bacterial activity and the abundance of HNA bacteria by simultaneous measurements of LNA and HNA cell distributions, chlorophyll $a$ and ${ }^{3} \mathrm{H}$-leucine uptake rates in temperate shelf waters of the northern Iberian Peninsula. We considered 3 zones based on hydrological properties. Significant correlations were found between bacterial activity (range 0.1 to 80 pmol Leu $\mathrm{l}^{-1} \mathrm{~h}^{-1}$ ) and both total and relative (range 28 to $84 \%$ ) HNA cell abundance for pooled data, but the ready use of HNA bacterial abundance as a proxy for activity in natural systems was questioned by the low percentage of variance explained (16\%). However, a detailed regional study of bottom-up effects revealed that the strength of this relationship increased significantly when bacteria were apparently controlled by phytoplankton substrate supply. Moreover, the relationship between mean biomass (overall range 12.4 to $21.2 \mathrm{fg} \mathrm{C} \mathrm{Cell}^{-1}$ ) and abundance-activity correlation coefficients in the 3 zones $(r=0.94, p=0.005, n=6)$ suggests that only at large cell sizes can we expect bacterial activity and production to be reasonably predicted by the abundance of HNA cells.
\end{abstract}

KEY WORDS: Bacterioplankton - Flow cytometry $\cdot$ Nucleic acid content $\cdot$ HNA cells $\cdot$ LNA cells Leucine uptake $\cdot$ Bacterial production

- Resale or republication not permitted without written consent of the publisher

\section{INTRODUCTION}

The variability in the abundance and activity of planktonic heterotrophic bacteria is key to the balance between production and consumption of organic matter in the oceans. The increased application of flow cytometry (FC) techniques has greatly improved our capability to estimate standing stocks of heterotrophic bacterioplankton in marine systems (Gasol \& del Giorgio 2000). Besides a considerable increase in the rate of sample processing, single-cell characteristics related to size, nucleic acid content, activity and physiological status can be readily provided along with absolute abundance (Sherr et al. 1999, Troussellier et al. 1999, Gasol \& del Giorgio 2000). The existence of prokaryotic cells with differing fluorescence levels after DAPI staining was first observed in image analysis (Sieracki
\& Viles 1992). However, it was the routine use of FC that permitted the consistent observation in in situ samples of at least 2 distinct clusters of heterotrophic prokaryotes based in their relative fluorescence after nucleic acid dye labeling (e.g. Li et al. 1995, Marie et al. 1996, Troussellier et al. 1999). Frequently, the fluorescence level, which is proportional to nucleic acid content (Marie et al. 1996), is also associated with a greater size. These 2 groups of bacteria have been termed HNA and LNA after their high and low nucleic acid content, respectively (Lebaron et al. 2001). In the present study, by '(relative) nucleic acid content', we will commonly refer to these 2 well-defined groups of cells rather than their actual fluorochrome signal.

Considerable attention has been paid to what HNA and LNA cells represent in terms of bacterial activity (e.g. Gasol et al. 1999, Lebaron et al. 2001, Zubkov et 
al. 2004), usually estimated as the incorporation rate of radiolabeled leucine or thymidine (Zubkov et al. 2001, Servais et al. 2003, Longnecker et al. 2005). A number of field reports (e.g. Li et al. 1995, Corzo et al. 2005, Calvo-Díaz \& Morán 2006) have shown that HNA numbers are usually more variable, both geographically and vertically, than those of LNA, indirectly suggesting that HNA cells are the most dynamic members of the community. Laboratory experiments with addition of organic substrates and nutrients have demonstrated that HNA bacteria constitute the 'ready to respond' fraction, while LNA cells would be dead or dormant (Gasol et al. 1999, Lebaron et al. 2001, Vaqué et al. 2001), but this view has been challenged in the past few years (e.g. Jochem et al. 2004, Zubkov et al. 2004, Sherr et al. 2006). For instance, Zubkov et al. (2001) and Longnecker et al. (2005) have demonstrated that HNA and LNA bacteria may exhibit similar rates of leucine incorporation (cf. Servais et al. 2003), and it has been recently shown that the relationship between activity and nucleic acid content varies with location along the inshore-offshore gradient (Sherr et al. 2006) and depth (Scharek \& Latasa 2007, this issue), hence suggesting a more general relationship with the trophic state of the system. Moreover, little is known regarding the factors affecting the observed association of increased HNA bacterial numbers and higher activity of the whole community in the laboratory.

In view of these unclear results, and in spite of the already established routine measurement of both HNA and LNA cell distribution in oceanographic surveys, it would appear questionable to summarize the large variability of bacterial metabolic states (Smith \& del Giorgio 2003) into just 2 groups of cells. Yet, comprehensive studies in natural environments testing the actual relationship between nucleic acid content and substrate uptake, and specifically the usefulness of HNA abundance as a proxy for bacterial activity, have seldom been attempted. As total numbers of bacteria are much less variable than their activity levels (e.g. del Giorgio et al. 1996), employment of the relative contribution of HNA to total numbers (\%HNA) has been proposed as a useful index (Jellett et al. 1996) that sometimes replaces reporting absolute abundances (Gasol et al. 1999, Šimek et al. 2005). Typical $\%$ HNA values in the field range from 15 to $90 \%$ (Li et al. 1995, Jellett et al. 1996, Servais et al. 2003).

In the present study, we gathered an extensive data set of HNA and LNA bacterial distributions, cell sizes and biomasses and ${ }^{3} \mathrm{H}$-leucine uptake rates in the upper layers of the north Iberian Peninsula continental shelf $\left(41\right.$ to $44^{\circ} \mathrm{N}, 2$ to $9^{\circ} \mathrm{E}$ ), with the following aims: (1) to assess whether HNA cells are consistently responsible for higher bacterial activities under natural conditions and (2) to explore the factors that determine the variability in HNA and LNA bacterial abundance and activity in these waters. Specifically, we looked at whether the response of bacterioplankton biomass and activity to substrate supply (bottom-up control) has an effect on the observed variation in HNA cell abundance as a proxy for total leucine uptake. For this purpose, we divided the study area into 3 zones based on hydrological properties. Finally, we explored the effect of bacterial cell size on the linkage between high nucleic acid content and activity.

\section{MATERIALS AND METHODS}

Samples for the simultaneous determination of heterotrophic bacterial abundance and activity were taken from 4 to 5 depths (from the surface down to $100 \mathrm{~m}$ depth or the near-bottom at shallower stations) at 24 stations along the continental shelf and shelfbreak of the northwestern and north coasts of the Iberian Peninsula (see Fig. 1A) during the PELACUS 0303 cruise, on board the RV 'Thalassa'. Sampling started at Stn 1 on 21 March 2003 and finished at Stn 24 on 12 April 2003. All stations were located over the continental shelf, with water depths ranging from 25 to $237 \mathrm{~m}$, except at Stns 10 (305 m), 15 (734 $\mathrm{m})$ and $21(1090 \mathrm{~m})$. At each station vertical profiles of temperature, salinity and in vivo fluorescence were taken with a SeaBird 25 CTD equipped with a Sea-Point fluorometer. Water samples were taken from 51 Niskin bottles mounted on a rosette sampler attached to the CTD.

Chlorophyll a. Biomass of phytoplankton was estimated from chlorophyll a (chl a) concentrations measured in $90 \%$ acetone extracts of samples collected at 5 depth levels between the surface and $100 \mathrm{~m}$ depth. Samples were size fractionated through a series of nets $(20 \mu \mathrm{m})$ and polycarbonate filters (5 and $2 \mu \mathrm{m})$ and finally recovered onto Whatman GF/F filters. Photosynthetic pigments were extracted overnight at $-20^{\circ} \mathrm{C}$, and concentrations of chl $a, b$ and $c 1+c 2$ were computed from fluorescence measurements (Neveux \& Lantoine 1993). In the present study, however, only total chl $a$, as the sum of all fractions, is considered. Whenever a chl a measurement was not available (on 10 occasions), the in situ fluorometer value was used after calibration with the analytical values measured during the cruise ( $\mathrm{chl} a=0.07+13.53$ in situ fluorescence, $\left.\mathrm{r}^{2}=0.47, \mathrm{p}<0.001, \mathrm{n}=110\right)$.

HNA and LNA bacterial abundance and size. The abundance of HNA and LNA bacteria was determined by flow cytometry. Samples $(1.8 \mathrm{ml})$ were immediately fixed with $1 \%$ paraformaldehyde and $0.05 \%$ glutaraldehyde solution (final concentrations) for $10 \mathrm{~min}$ in the dark before being stored frozen in liquid $\mathrm{N}_{2}$. Once 
in the laboratory, they were kept at $-80^{\circ} \mathrm{C}$ until analysis with a FACSCalibur (Becton-Dickinson) bench top flow cytometer, equipped with a laser emitting at $488 \mathrm{~nm}$. Samples were then left to thaw at room temperature and stained for $10 \mathrm{~min}$ with $2.5 \mu \mathrm{mol} \mathrm{l}^{-1}$ of the nucleic acid fluorochrome SYTO-13 (Ref. S-7575, Molecular Probes). Then, $10 \mu \mathrm{l}$ of a solution of $1 \mu \mathrm{m}$ fluorescent beads (Ref. F-13081, Molecular Probes) of a known concentration was added as an internal standard and used to normalize values of single-cell variables. Aliquots $(0.4 \mathrm{ml})$ were run at low flow rate $\left(\sim 15 \mu \mathrm{lmin}^{-1}\right)$ until acquisition of 10000 events. HNA and LNA cells were distinguished by their different signals of right-angle light scattering (RALS) and green fluorescence (FL1). We were able to clearly differentiate between HNA and LNA bacteria in all samples. A third high nucleic acid group of bacteria, characterized by higher RALS and FL1 than HNA cells, was frequently observed in the cytograms. Their abundance (mean $4.23 \times 10^{3}$ cells $\mathrm{ml}^{-1}$ ) was 2 orders of magnitude lower than the other 2 groups, with an average contribution to total bacterial biomass of $2.8 \pm$ $1.0 \%$. Since this group is not always detected in the study area, we decided to only focus on the widespread HNA and LNA groups of cells. Synechococcus were easily distinguished from heterotrophic bacteria by their higher red fluorescence (FL3) signal. An empirical calibration between RALS and cell diameter (cell diameter $=0.91+0.34 \log$ RALS, $\mathrm{r}^{2}=0.57, \mathrm{p}=$ 0.049, n = 7; see Calvo-Díaz \& Morán 2006 for details) was used to estimate biovolume, which was converted into bacterial carbon biomass (BB) using the allometric relationship of Norland (1993): BB (fg cell ${ }^{-1}$ ) $=120$ (biovolume $)^{0.7}$. Given the uncertainties associated with size and biomass estimates, our values should be considered with caution if they are to be compared with other studies.

Bacterial activity. Bacterial activity was estimated from leucine (Leu) uptake rates. Four replicate samples $(1 \mathrm{ml})$ were placed into polypropylene translucent Eppendorf tubes and incubated on board at simulated in situ temperatures $\left( \pm 0.5^{\circ} \mathrm{C}\right)$ after addition of $50 \mathrm{nmol}$ $\mathrm{l}^{-1}$ (final concentration) of ${ }^{3} \mathrm{H}-\mathrm{Leu}$ (Kirchman 1993). Samples were incubated under dim light $(\sim 20 \mu \mathrm{mol}$ quanta $\mathrm{m}^{-2} \mathrm{~s}^{-1}$ ), mimicking mixed layer depth levels (Morán et al. 2001). The Eppendorf walls absorbed only $\sim 8 \%$ of incident irradiance. Incubations lasted 0.5 to $1 \mathrm{~h}$ and were terminated by the addition of $100 \mu \mathrm{l}$ of $50 \%$ trichloroacetic acid (TCA). Labeled proteins were recovered by centrifugation in 2 steps. Liquid was aspirated after each centrifugation with a Pasteur pipette at low vacuum pressure. Pellets were rinsed with $1 \mathrm{ml}$ of $5 \%$ TCA before the second centrifugation. For each depth 2 TCA-killed controls were also inoculated with ${ }^{3} \mathrm{H}$-Leu and incubated as regular sam- ples. Radioactivity was measured on land within 1 mo after completion of the cruise with a LKB-Wallac liquid scintillation counter. Detailed information on the incubation procedures can be found in Valencia et al. (2003).

Bottom-up control of bacteria. Chl a concentration was used as a proxy of recent photosynthate availability for bacteria. However, bacteria may rely on sources other than phytoplankton-derived dissolved organic carbon (DOC). Independent of the origin of the substrates used for bacterial growth, resource limitation of bacteria or bottom-up control can be estimated by the method of Ducklow (1992), which extended upon the analysis of Billen et al. (1990). The method assumes steady state and consists in assessing the value and significance of the slope of the ordinary least squares linear regression between log-transformed values of bacterial production and biomass. According to regression slope values, the strength of bottom-up control would range from weak $(<0.4)$ through moderate $(0.4$ to 0.6$)$ and strong (>0.6). Since empirical carbonto-Leu conversion factors were not determined during this cruise, the theoretical factor of $1.55 \mathrm{~kg} \mathrm{C} \mathrm{mol}^{-1}$ Leu, assuming no isotope dilution (Simon \& Azam 1989), was used to estimate bacterial production. Conversion factors in the central Cantabrian Sea (A. CalvoDíaz \& X. A. G. Morán pers. comm.) show very similar values for late winter and early spring $(1.26 \pm 0.32 \mathrm{SD}$, average of 6 values obtained at 3 shelf stations ranging from 20 to $160 \mathrm{~m}$ depth).

Statistical analysis. Statistical analyses were performed with STATISTICA software. With the exception of the percentage of HNA cells (\%HNA), all variables compared were log-transformed in order to attain normality and homogeneity of variances. Kolmogorov-Smirnoff tests confirmed the normal distributions of variables after transformation. Sample sizes for the different variables measured (n) ranged between 101 and 112. Simple Model I linear regression was used to determine the degree of correlation between variables, as correlation coefficients are not affected by the choice of the model. Although Model II regressions are more appropriate when both $x$ and $y$ variables have errors associated, in its original formulation Ducklow (1992) used Model I, so we kept this model for discussion on the significance of bottom-up control in our samples (see above). Since it is not clear whether Bonferroni correction is needed in ecological studies (Moran 2003), statistical results were interpreted according to the customarily accepted 0.05 p-level. One-way ANOVAs and Student-Newman-Keuls post hoc tests were performed for the analysis of geographical differences. Data were grouped by location as explained in the 'Results; Regional variability'. Finally, we tested whether there was any size depen- 
dence in the relationship between bacterial cell abundance and activity. To test this hypothesis we correlated mean individual biomass with the respective correlation coefficients between HNA and LNA cell abundance and total activity in the 3 zones. This type of meta-analysis has been used to identify general trends of species interactions and mean temperature among regions (e.g. Worm \& Myers 2003, Richardson \& Schoeman 2004). In order to minimize autocorrelation between samples, we used water-column averages of individual HNA and LNA cell biomass to estimate mean values at each zone.

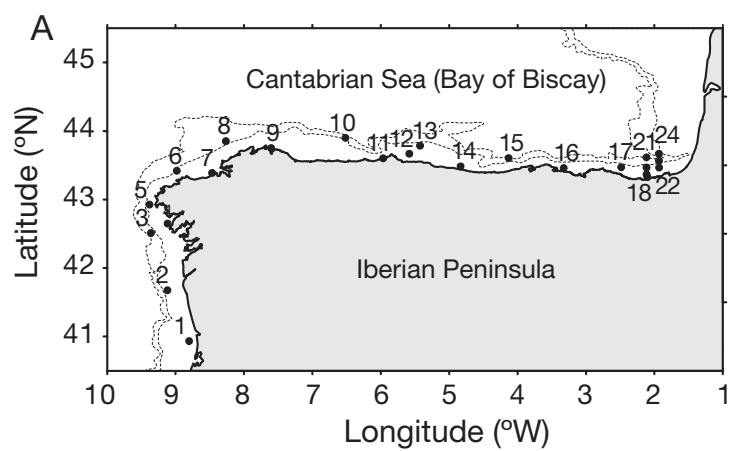

\section{Station}

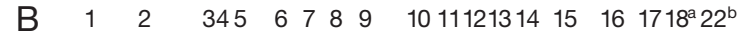
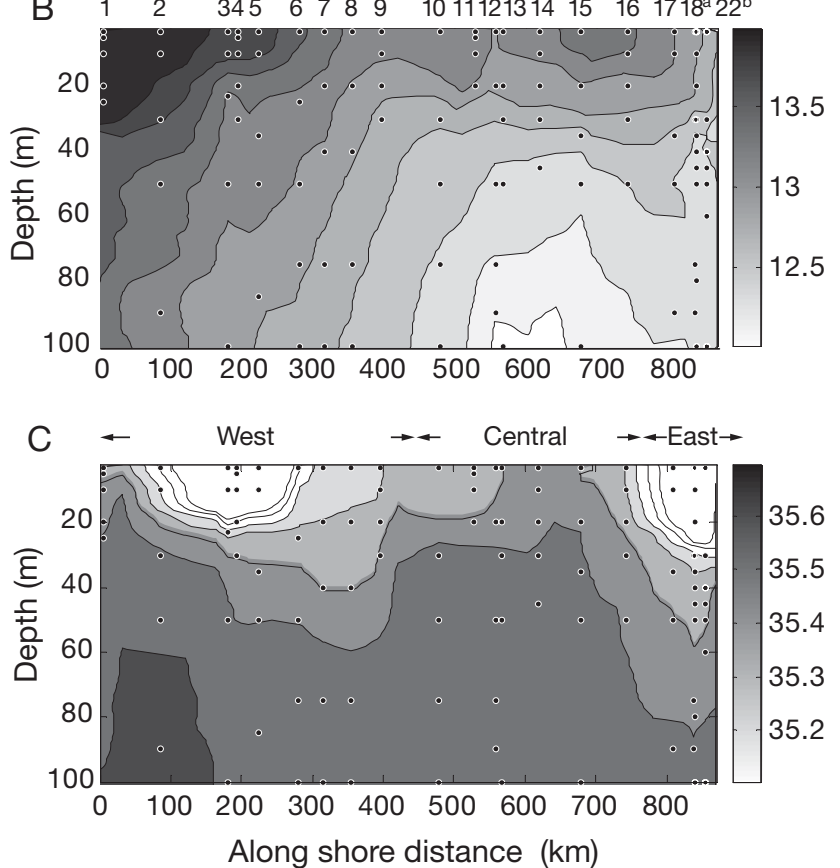

Fig. 1. (A) Sampling stations, (B) vertical distribution of temperature $\left({ }^{\circ} \mathrm{C}\right)$ and $(\mathrm{C})$ salinity in the geographical region surveyed. Dotted lines (A) represent 200 and $1000 \mathrm{~m}$ isobaths. The position of each station in the alongshore gradient is indicated at the top of (B). Dots indicate sampling depths. Geographical zones are also indicated $\left(18^{\mathrm{a}}\right.$ : Stns 18 to $21 ; 22^{\mathrm{b}}$ : Stns 22 to 24 )

\section{RESULTS}

Stratification of the water column was obvious at most stations, with progressively shallower mixed layers as we moved eastward ( $20 \mathrm{~m}$ at $2^{\circ} \mathrm{W}$ compared with $\sim 40 \mathrm{~m}$ at $9^{\circ} \mathrm{W}$ ). Fig. 1B shows that vertical gradients of temperature were weak (generally $<1^{\circ} \mathrm{C}$ ) relative to salinity (Fig. 1C), which attained lower values in areas with higher continental runoff, from the Rías Baixas in the western part and the Adour River in the east.

\section{Chlorophyll $a$ and bacterial abundance}

Fig. 2 shows an apparent lack of geographical trends for chl $a$ and total bacterial abundance (BN). Mean $\pm \mathrm{SE}$

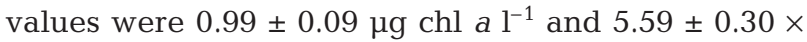
$10^{5}$ cells $\mathrm{ml}^{-1}$, respectively. Relatively low chl a values at most of the stations are indicative of not fully developed spring blooms. On average, HNA cells were characterized by a 4.3-fold higher relative FL1 fluorescence than LNA cells, a measure of the relative nucleic acid content of both groups (Marie et al. 1997). This ratio was similar to the values reported by Lebaron et al. (2001) and varied little across the study region as

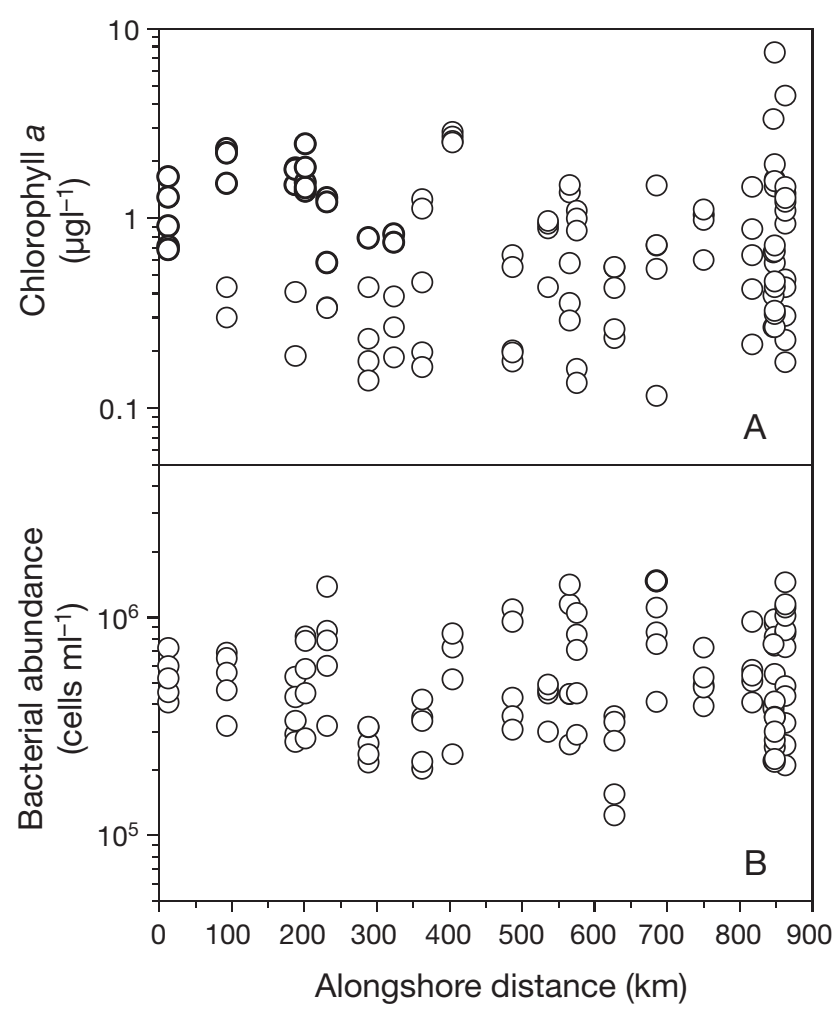

Fig. 2. Alongshore distribution of (A) chlorophyll a concentration and (B) total bacterial abundance at all sampling depths within each station 
previously found in the NE Pacific (Sherr et al. 2006). The contribution of HNA bacteria to total numbers (\%HNA) ranged from 28 to $84 \%$, averaging $57 \pm 1 \%$ for the whole data set. Overall, LNA abundance was more variable than that of HNA (coefficient of variation, CV, of 76 and $62 \%$, respectively). The HNA group was the only one significantly correlated with chl $a(r=0.57, \mathrm{p}<$ $0.001, \mathrm{n}=107$ ); hence, HNA cells were responsible for the overall relationship between $\mathrm{BN}$ and chl $a(\mathrm{r}=0.46$, $\mathrm{p}<0.001, \mathrm{n}=107)$. The abundance of HNA bacteria showed a weak, significant decrease with depth $(\mathrm{r}=$ $-0.36, p<0.001)$, while LNA bacteria did not.

\section{Regional variability}

Despite the relative uniformity of total numbers (Fig. 2B), the distributions of water-column-averaged abundance of LNA and HNA bacteria were not homogeneous (Fig. 3A), with maxima of \%HNA (>60\%) in areas of minimum salinity close to the endpoints of the study region and values around $50 \%$ in between (Fig. 3B). Bacterial activity also showed a distinct geographical trend (Fig. 3C), with values $>10$ pmol Leu l-1 $\mathrm{h}^{-1}$ roughly coincident with peaks of \%HNA and lowest values $\left(<1 \mathrm{pmol} \mathrm{Leu} \mathrm{l}^{-1} \mathrm{~h}^{-1}\right)$ in the central Cantabrian Sea (Stns 10 to 15). A cluster analysis based on water-column averages of temperature and salinity using Euclidean distance and Ward's method (data not shown) clearly ordered the stations according to longitude. We accordingly grouped the stations into 3 zones as done in previous works (see Bode et al. 2001, 2002, Calvo-Díaz et al. 2004), based on the presence of strong hydrological signatures very similar to those found during this cruise. The zones are hereafter named as follows (see Fig. 1): West $\left(41^{\circ} \mathrm{N}, 9^{\circ} \mathrm{E}\right.$ to $\left.44^{\circ} \mathrm{N}, 7^{\circ} \mathrm{E}\right)$, Central $\left(7\right.$ to $\left.3^{\circ} \mathrm{E}\right)$ and East $\left(<3^{\circ} \mathrm{E}\right)$. HNA bacteria were significantly more abundant in the East zone, while LNA peaked in the Central zone (Fig. 3A, Table 1). \%HNA bore no significant relationship with total numbers for any data pooled, but they were significantly correlated in the West and Central zones. Strikingly, the \%HNA-BN correlation was positive in the West zone $(r=0.39, p=0.015, n=39)$, but negative in the Central zone $(\mathrm{r}=-0.59, \mathrm{p}<0.001$, $\mathrm{n}=34$ ). Bacterial activity, which spanned over almost 4 orders of magnitude $\left(0.1\right.$ to $\left.80 \mathrm{pmol} \mathrm{Leu} \mathrm{l}^{-1} \mathrm{~h}^{-1}\right)$, was significantly lower in the Central zone compared with the other 2 zones (Table 1 ).

\section{Individual cell size and biomass of LNA and HNA bacteria}

Pooled data of bacterial cell size (0.44 to $0.53 \mu \mathrm{m})$ were significantly correlated with nucleic acid content estimated from relative fluorescence $(r=0.44, p<$ $0.001, \mathrm{n}=203$ ). Biovolumes, which ranged from 0.039 to $0.080 \mathrm{\mu m}^{3}$, were similar to previous reports in the $\mathrm{N}$ Atlantic (Sieracki \& Viles 1992) and the Mediterranean (Gasol et al. 1995, Vaqué et al. 2001). Corresponding individual biomass varied from 12.4 to $21.2 \mathrm{fg} \mathrm{C} \mathrm{cell}^{-1}$. The highest differences between mean LNA and HNA cell carbon were found in the West zone, with 15.3 and 17.4 $\mathrm{fg} \mathrm{C} \mathrm{cell}^{-1}$, respectively. While mean cell carbon of HNA bacteria consistently decreased eastwards, that of LNA bacteria was less variable $\left(\sim 15 \mathrm{fg} \mathrm{C} \mathrm{Cell}^{-1}\right.$; Table 1).

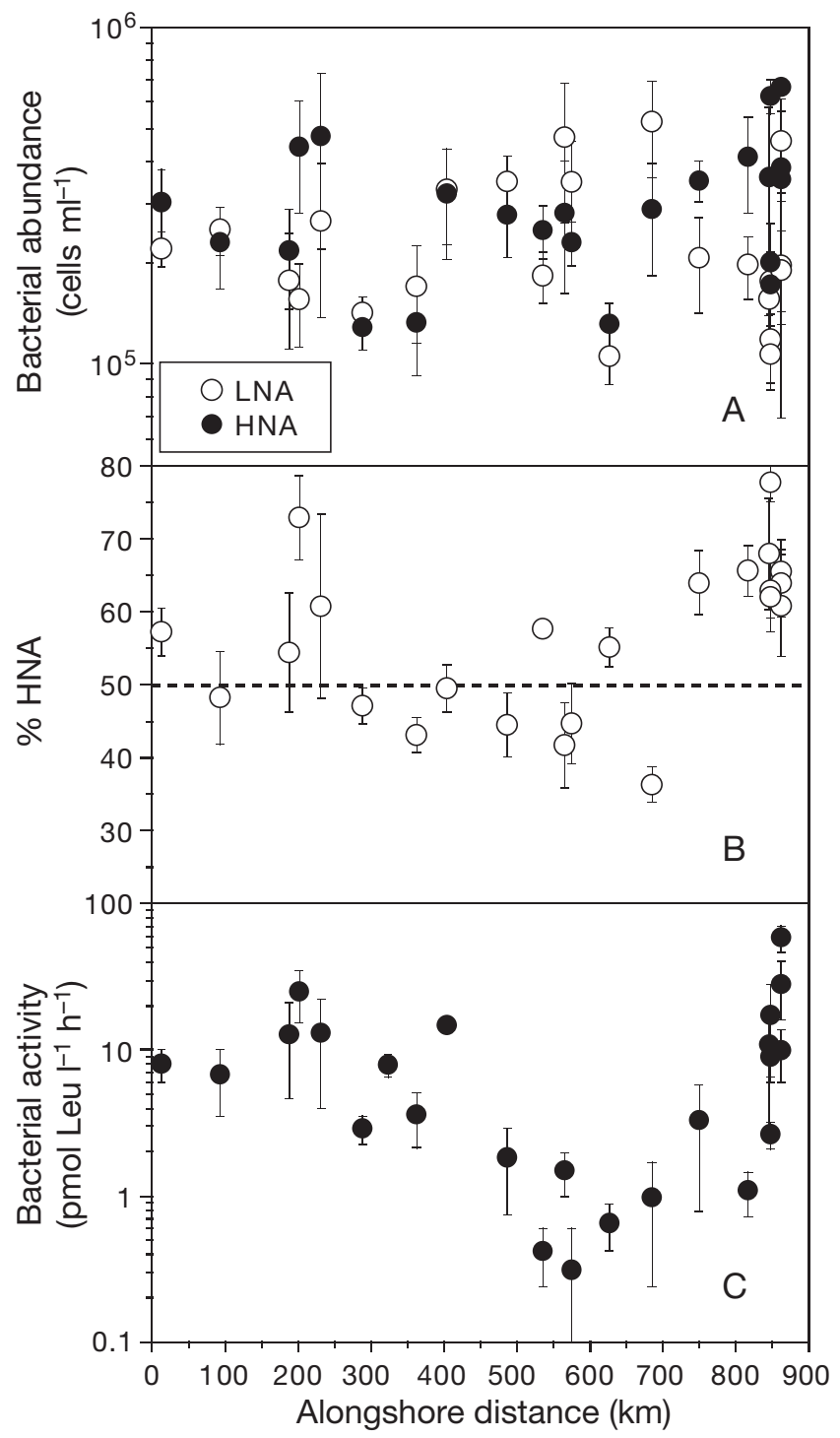

Fig. 3. Alongshore distribution of water-column averages $( \pm \mathrm{SD})$ of $(\mathrm{A})$ the abundance of LNA (low nucleic acid) and HNA (high nucleic acid) bacteria, (B) the percentage of HNA bacteria and (C) leucine incorporation rates. Dashed line in (B) represents equal contribution of LNA and HNA cells to total numbers 
Table 1. Mean, ranges and coefficients of variation (CV) for all data pooled of temperature, salinity, chlorophyll a and bacterial variables in the 3 geographical zones considered. Different superscripts indicate significant differences among regions (ANOVA, Student-Newman-Keuls post hoc test, $\mathrm{p}<0.05)$. n: number of data available; LNA: low nucleic acid; HNA: high nucleic acid

\begin{tabular}{|c|c|c|c|c|c|c|c|c|c|}
\hline Zone & $\begin{array}{c}\text { Temp. } \\
\left({ }^{\circ} \mathrm{C}\right)\end{array}$ & Salinity & $\begin{array}{c}\text { Chl a } \\
\left(\mu g l^{-1}\right)\end{array}$ & $\begin{array}{c}\text { LNA } \\
\text { abund. } \\
\left(\times 10^{5} \text { cells } \mathrm{ml}^{-1}\right)\end{array}$ & $\begin{array}{c}\text { HNA } \\
\text { abund. } \\
\left(\times 10^{5} \text { cells } \mathrm{ml}^{-1}\right)\end{array}$ & $\begin{array}{l}\text { \%HNA } \\
1 \text { ) }\end{array}$ & $\begin{array}{c}\text { LNA } \\
\text { biomass } \\
(\mathrm{fg} \mathrm{C} \mathrm{cell-1})\end{array}$ & $\begin{array}{c}\text { HNA } \\
\text { biomass } \\
\left(\mathrm{fg} \mathrm{Cell}^{-1}\right)\end{array}$ & $\begin{array}{c}\text { Leucine } \\
\text { uptake rate } \\
\left(\mathrm{pmol}^{-1} \mathrm{~h}^{-1}\right)\end{array}$ \\
\hline \multicolumn{10}{|l|}{ West } \\
\hline Mean & $13.2^{\mathrm{a}}$ & $35.28^{\mathrm{a}}$ & $1.10^{\mathrm{a}}$ & $2.07^{\mathrm{a}}$ & $2.89^{\mathrm{a}}$ & $56^{\mathrm{a}}$ & $15.3^{\mathrm{a}}$ & $17.4^{\mathrm{a}}$ & $10.9^{\mathrm{a}}$ \\
\hline Range & $12.7-14.0$ & $34.04-35.61$ & $0.14-2.86$ & $0.48-4.49$ & $0.83-11.15$ & $38-84 \%$ & $12.4-17.4$ & $15.1-21.2$ & $0.5-38.7$ \\
\hline $\mathrm{CV}(\%)$ & 3 & 1.2 & 75 & 48 & 69 & 10 & 7 & 9 & 91 \\
\hline \multicolumn{10}{|l|}{ Central } \\
\hline Mean & $12.8^{\mathrm{b}}$ & $35.48^{\mathrm{b}}$ & $0.67^{\mathrm{a}}$ & $3.35^{\mathrm{b}}$ & $2.63^{\mathrm{a}}$ & $48^{\mathrm{b}}$ & $15.8^{\mathrm{b}}$ & $16.3^{\mathrm{b}}$ & $1.3^{\mathrm{b}}$ \\
\hline Range & $11.8-13.5$ & $35.32-35.58$ & $0.12-1.50$ & $0.54-9.72$ & $0.70-5.43$ & $28-72 \%$ & $14.1-18.4$ & $13.8-20.9$ & $0.1-9.1$ \\
\hline CV $(\%)$ & 3 & 0.2 & 60 & 78 & 44 & 25 & 6 & 11 & 124 \\
\hline \multicolumn{10}{|l|}{ East } \\
\hline Mean & $12.6^{\mathrm{c}}$ & $35.21^{\mathrm{a}}$ & $1.17^{\mathrm{a}}$ & $1.93^{\mathrm{a}}$ & $3.97^{\mathrm{b}}$ & $67^{c}$ & $15.0^{\mathrm{a}}$ & $15.4^{\mathrm{C}}$ & $16.8^{a}$ \\
\hline Range & $12.4-13.2$ & $34.50-35.54$ & $0.17-7.53$ & $0.39-7.79$ & $0.14-8.42$ & $46-81 \%$ & $13.8-16.8$ & $12.9-18.6$ & $0.7-79.6$ \\
\hline CV (\%) & 2 & 1.0 & 124 & 69 & 57 & 15 & 6 & 9 & 119 \\
\hline \multicolumn{10}{|l|}{ All } \\
\hline Mean \pm SE & $12.9 \pm 0.0$ & $35.33 \pm 0.03$ & $0.99 \pm 0.09$ & $2.47 \pm 0.18$ & $3.21 \pm 0.19$ & $57 \pm 1$ & $15.4 \pm 0.1$ & $16.4 \pm 0.2$ & $9.8 \pm 1.3$ \\
\hline $\mathrm{n}$ & 106 & 101 & 112 & 107 & 107 & 107 & 107 & 106 & 112 \\
\hline
\end{tabular}

\section{Relationships between nucleic acid content, activity and biomass}

As suggested by Fig. 3, overall leucine incorporation rates were significantly correlated with the percentage of HNA cells (Fig. 4), although the corresponding least squares linear regression explained a low percentage of variance $\left(\log \mathrm{Leu}=-0.54+0.02 \%\right.$ HNA, $\mathrm{r}^{2}=0.16$, $\mathrm{p}<0.001, \mathrm{n}=106)$. If HNA cells were the only ones really active, a significant correlation of their absolute numbers with Leu incorporation rates could be expected rather than only their percentage. While both

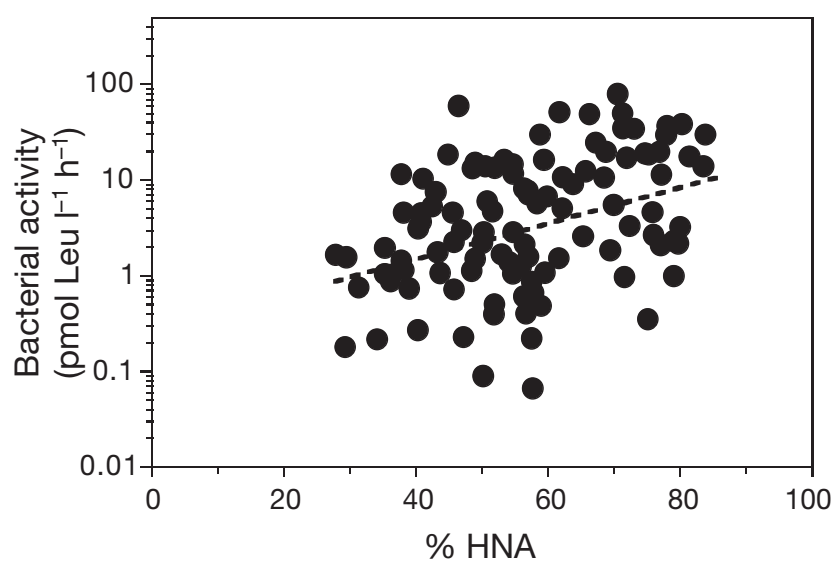

Fig. 4. Relationship between the percentage of HNA bacteria and leucine incorporation rates for the whole data set. Dashed line represents fitted ordinary least squares linear regression: $\log$ Leu $=-0.54+0.02 \%$ HNA; $^{2}=0.16, p<0.001, \mathrm{n}=106$ total numbers and LNA cell abundance bore no significant correlation, HNA cell abundance was still weakly, but significantly, correlated with bacterial activity $(\mathrm{r}=0.31, \mathrm{p}=0.001, \mathrm{n}=107)$. However, different HNA cell abundance-activity patterns were obtained for the 3 geographical zones (Fig. 5A,D,G). A significant positive correlation held in the West and Central zones $(\mathrm{r}=0.59, \mathrm{p}<0.001, \mathrm{n}=39$ and $\mathrm{r}=0.34$, $\mathrm{p}=0.050, \mathrm{n}=34$, respectively), but not in the East zone ( $\mathrm{r}=-0.03, \mathrm{p}=0.87, \mathrm{n}=34)$, while the abundance of LNA bacteria was not significantly correlated with Leu incorporation rates in any region. HNA abundance was, in turn, significantly correlated with chl a in all zones, with much more similar coefficients of correlation (West, $\mathrm{r}=0.56, \mathrm{p}<0.001, \mathrm{n}=39$; Central, $\mathrm{r}=0.69$, $\mathrm{p}<0.001, \mathrm{n}=34$; East, $\mathrm{r}=0.62, \mathrm{p}<0.001, \mathrm{n}=34$ ).

Geographical differences in the correlations between bacterial abundance and activity could not be readily explained by hydrographic (Fig. 1) or biological variables, (Figs. 2 \& 3). For instance, salinity, \%HNA and chl $a$ attained similar values in the East and West zones despite their great differences in the HNA abundance-activity relationships (Fig. 5A,G). Therefore, we explored the degree of bottom-up regulation of bacterial assemblages in the 3 zones with 2 complementary approaches. First, the relationship between Leu incorporation rates and chl a as a proxy for fresh photosynthate made available to bacteria is shown (Fig. 5B,E,H). Significant correlations were again only found in the West and Central zones, especially in the West zone $(\mathrm{r}=0.72, \mathrm{p}<0.001, \mathrm{n}=44)$. The second method, based on the analysis of the linear regression 
West
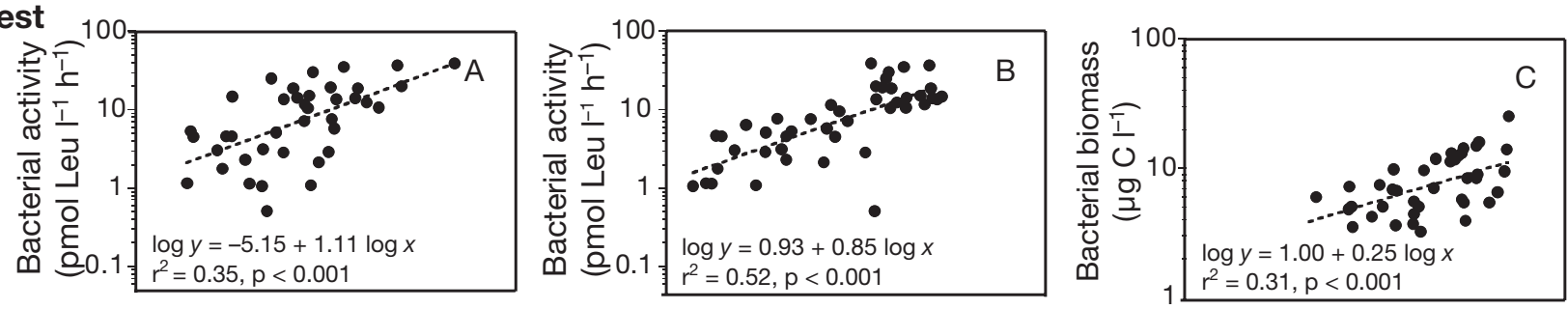

Central
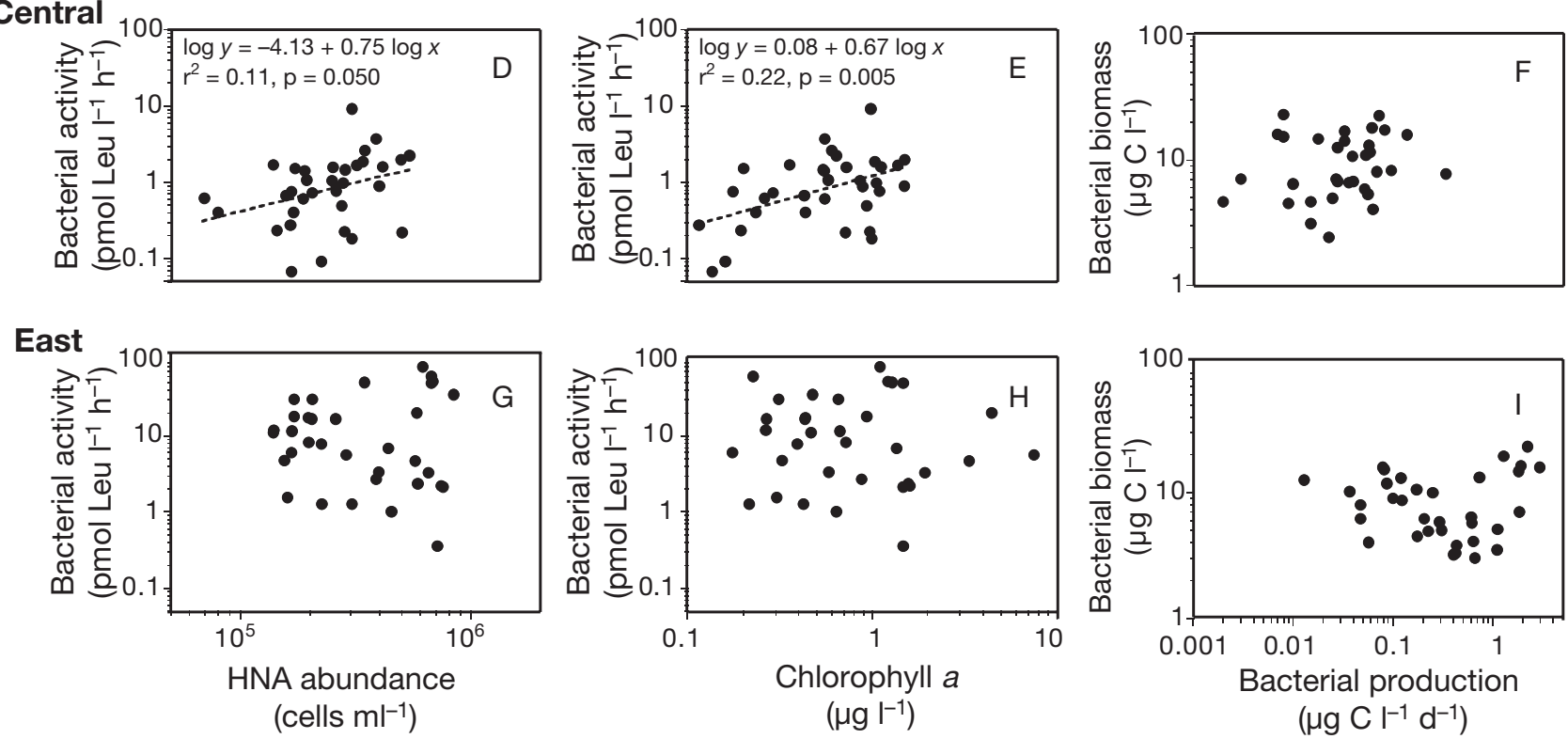

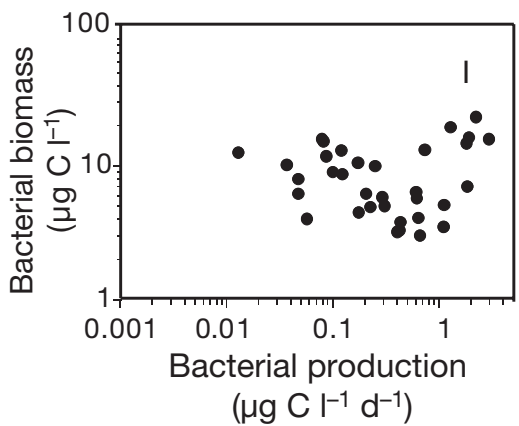

Fig. 5. Scatterplots for the 3 geographical zones of leucine incorporation rates versus abundance of HNA bacteria and chlorophyll a concentration, and of bacterial biomass versus bacterial production: (A, B, C) West zone (Stns 1 to 9), (D, E, F) Central zone (Stns 10 to 16) and (G, H, I) East zone (Stns 17 to 24). Only significant linear regressions (dashed lines) are represented

of BB on BP (Billen et al. 1990, Ducklow 1992), is also shown (Fig. 5C,F,I). This regression was only significant in the West zone $\left(\log \mathrm{BB}=0.77+0.25 \log \mathrm{BP} ; \mathrm{r}^{2}=\right.$ $0.31, \mathrm{p}<0.001, \mathrm{n}=39$ ), implying that $\mathrm{BB}$ was bottomup controlled there, although weakly, due to the low slope value (Ducklow 1992).

Finally, the role of cell size in determining the linkage of activity to changes in bacterial abundance was also assessed using the values obtained in the 3 zones. Average cell biomass of LNA and HNA bacteria was significantly and highly correlated $(\mathrm{r}=0.93, \mathrm{p}=0.006$, $\mathrm{n}=6$ ) with the respective abundance-activity correlation coefficients (Fig. 6), implying that higher bacterial abundances would result in activity increases only when cells are relatively large, as shown in Fig. 5A and D for HNA cells (17.4 and $16.3 \mathrm{fg} \mathrm{C} \mathrm{Cell}^{-1}$, respectively). Conversely, HNA abundance was not an indicator of activity when these bacteria were smaller (15.4 fg C cell ${ }^{-1}$ ) as in the East zone (Fig. 5G, Table 1), in spite of the maximum \%HNA values being attained there (Fig. 3B).

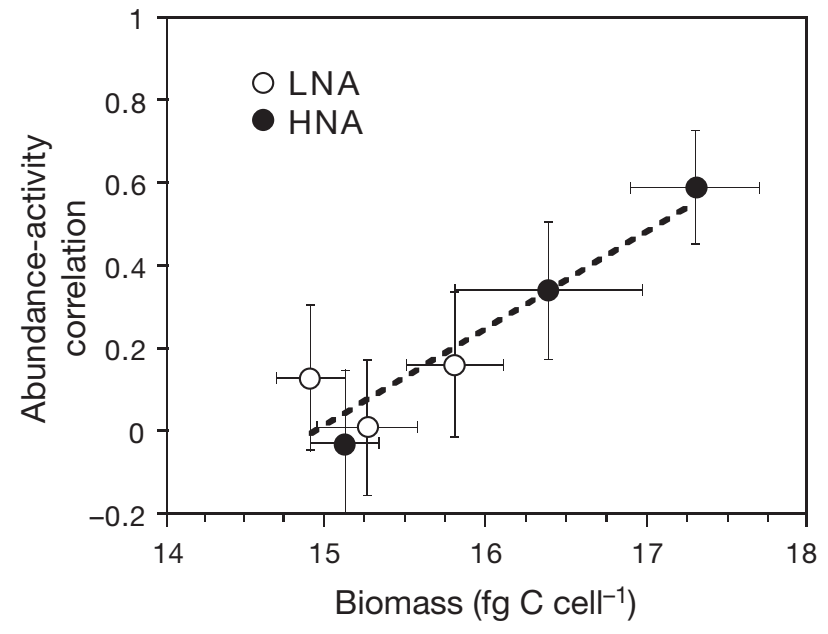

Fig. 6. Relationship between the correlation coefficients between the abundance of HNA and LNA bacteria and leucine incorporation rates ( $\mathrm{r}$ ) and cell carbon biomass for the 3 geographical zones. Error bars represent SE. Dashed line represents ordinary least squares linear regression: $\mathrm{r}=$ $-3.59+0.24$ cell biomass; $\mathrm{r}^{2}=0.88, \mathrm{p}=0.005, \mathrm{n}=6$ 


\section{DISCUSSION}

The extended geographical range covered ( 900 km; Fig. 1) allowed us to compare reasonably wide ranges of both bacterial activity and LNA and HNA cell abundance, with a negligible effect of temperature. Although it varied significantly among zones (Table 1), its overall range of variation $\left(11.8\right.$ to $\left.14.0^{\circ} \mathrm{C}\right)$ was too small to affect the observed distributions ( $\mathrm{Li}$ et al. 2004). The observed variability in the abundance of HNA and LNA bacteria compares well with the findings of Calvo-Díaz et al. (2004) and is especially consistent regarding the geographical distribution of \%HNA (Fig. 3, cf. their Fig. 3F). In the central Cantabrian Sea \%HNA varies seasonally from 31 to $91 \%$ (Calvo-Díaz \& Morán 2006), closely resembling the range found here (29 to $84 \%$ ). Maximum values are similar to those in other systems ( 80 to $90 \%$; Li et al. 1995, Jellett et al. 1996, Vaqué et al. 2001), but chl a values and Leu uptake rates were somewhat lower than expected for these waters during spring (Valencia et al. 2003).

\section{Nucleic acid content and activity of natural bacterial communities}

The absence of vertical variability in LNA cell numbers could be indicative of a more homogeneous, background component of the community (Gasol et al. 1999, Calvo-Díaz et al. 2004, Corzo et al. 2005). LNA cell abundance did not increase with increasing chl a or bacterial activity, as previously observed in natural samples (Morán et al. 2002b, 2004, Tadonléké et al. 2005) and in dilution-growth experiments (Gasol et al. 1999, Vaqué et al. 2001), altogether supporting their identification with inactive or dead cells, as proposed by some authors (Li et al. 1995, Jellett et al. 1996, Gasol et al. 1999). However, the finding that overall LNA bacterial abundance was more variable than that of HNA cells (76 vs. $62 \% \mathrm{CV}_{\text {; }}$ see also Table 1 ), if not an indirect result of factors acting on HNA bacteria, could suggest that this group of cells was able to show some response to environmental forcing (Seymour et al. 2005, Sherr et al. 2006). Growth of LNA as well as HNA cells was detected in simulated phytoplankton blooms by Wetz \& Wheeler (2004), and other studies have found higher growth rates of LNA cells relative to HNA at depth (Jochem et al. 2004, Scharek \& Latasa 2007). Following Smith \& del Giorgio (2003), LNA bacteria may simply be cells with lower cell-specific metabolic activity, as demonstrated in the Celtic Sea (Zubkov et al. 2001) and the California Current upwelling ecosystem (Longnecker et al. 2005), which, on occasion, might even prevail over HNA cells (Zubkov et al. 2001, 2004).
On the other hand, and contrary to observations in other areas (Morán et al. 2004, Corzo et al. 2005) or later in the year in the same region (Calvo-Díaz \& Morán 2006), HNA cell abundance and \%HNA displayed a weak, but significant decrease with depth, indicating that HNA cells could respond to the increased availability of photosynthate in the shallower layers of the water column. The existence of a tight trophic linkage or 'coupling' (Morán et al. 2002a) between HNA bacteria and phytoplankton in early spring is therefore suggested by our data. The overall positive, although weak (as in Sherr et al. 2006), relationship between chl $a$ and BN found during the cruise was only attributable to HNA cells. Although we did not attempt simultaneous determinations of dissolved photosynthate supply to bacteria, these results support the view that the HNA group is the group most capable of responding to increased inputs of organic substrates (Wetz \& Wheeler 2004). Interestingly, remarkably similar correlations between chl $a$ and the abundance of HNA bacteria were obtained in the 3 regions $(r=0.55$ to 0.69 ), in spite of the different responses in activity (Fig. 5). This finding suggests that the standing stock variables chl $a$ and HNA cell abundance have similar time-scales of response, while activity rates would vary largely at shorter scales, with little or no effect on the relative nucleic acid content distribution. This result is also consistent with the hypothesis of Zubkov et al. (2004) that a larger genome would make HNA cells dominant under meso- to eutrophic conditions, while LNA cells would mostly rely on regenerated nutrients.

The increase in HNA cells is commonly taken as an indication of increases in bacterial activity and growth (e.g. Gasol \& del Giorgio 2000, Lebaron et al. 2001, Oliver et al. 2004). With all data pooled, this was the only group that was significantly and positively correlated with Leu incorporation rates, and therefore responsible for the significant relationship between \%HNA and Leu uptake (Fig. 4), confirming previous reports (Vaqué et al. 2001). Several studies have shown that HNA cells contribute a larger fraction of total Leu uptake than LNA cells (Servais et al. 1999, 2003, Lebaron et al. 2001). Unexpectedly, an increase in total numbers was not followed by a concurrent relative increase in HNA cells for the whole data set. However, when we examined possible geographical differences, $\%$ HNA was found to be positively correlated with total numbers in the West zone, but negatively in the Central zone, with no significant correlation in the East one. These differences were probably behind the low percentage of variance in activity explained by both total and relative (Fig. 4) HNA cell abundance. Within the HNA cell group, single-cell Leu incorporation rates have been shown to vary by as much as 7 -fold (Lebaron et al. 2001). Certainly, $<20 \%$ of total 
variance explained does not encourage the use of HNA bacteria distribution or \%HNA as a routine, alternative method to estimate bacterioplankton activity in the field. However, by binning the data set into geographical zones, we were able to gain some insight into the factors that affect the predictive capacity of HNA cell abundance as an activity index.

\section{Role of bottom-up control}

Maxima of \%HNA and bacterial activity were generally coincident (Fig. 3) and associated with lower salinities $(\mathrm{r}=-0.57, \mathrm{p}=0.007, \mathrm{n}=21$ for $\%$ HNA and $\mathrm{r}=-0.51$, $\mathrm{p}=0.015, \mathrm{n}=22$ ). Changes in \%HNA could indicate a different phylogenetic composition of bacterial assemblages in oceanic waters and in freshwater-influenced coastal waters (e.g. del Giorgio \& Bouvier 2002). However, the different relationships between HNA cell abundance and activity found in the West and East zones (Fig. 5A,G), both characterized by lower salinities (Fig. 1C), led us to look for the possible existence of different control processes of bacterioplankton in the 2 zones. The degree of resource control of bacteria was approached here in 2 manners, namely the relationship between bacterial activity and chl a as a surrogate for dissolved primary production (Morán et al. 2002a) and the relationship between bacterial biomass and production (Billen et al. 1990, Ducklow 1992). Both analyses showed a remarkably similar geographical pattern. As for HNA abundance and bulk activity, the correlation coefficients between bacterial activity and chl a decreased from the West to the East zone, where it was lost (Fig. 5B,E,H), suggesting a longitudinal gradient in the relative contributions of autochthonous and allochthonous carbon sources for bacterial metabolism and growth. Freshwater-associated inputs of dissolved organic matter (DOM) in the study region are usually greatest in the East zone (Bode et al. 2001). It must be borne in mind that the existence of a significant relationship between Leu uptake and chl a does not necessarily mean that bacteria can fulfill their substrate requirements solely with phytoplankton (Pace \& Cole 1996, Morán et al. 2002a,b). Morán et al. (2002b) observed a similar relationship in 2 surveys in the West zone continental shelf, yet bacteria required additional sources to the measured phytoplankton extracellular release rates. These results could also be explained by a higher relative importance of protistan predation or viral lysis as we moved eastwards. In the light of recent reports of high respiration rates of Leu during incubations (Alonso-Sáez et al. 2007), a regional difference in the amount of Leu being respired, in turn, determined by the nature of available DOM, is another possible factor not addressed in this study.
The analysis of the BB-BP relationship proposed by Ducklow (1992) has proved useful for inferring bacterial bottom-up control in oceanic waters (Dufour \& Torréton 1996), and its conclusions are coherent with other techniques (Gasol et al. 2002). Although BP and substrate use are not proportional when a wide range of trophic conditions is considered (Dufour \& Torréton 1996), the variability of chl a as a proxy for trophic state during the survey (Fig. 2A) was only 1 order of magnitude; hence, this did not seriously compromise our conclusions. Thus, bacterial biomass was controlled by substrate supply only in the West zone (Fig. 5C), while in the Central and East zones bottom-up control was not apparent (Fig. 5F,I). HNA cell abundance was more variable in the West zone (Table 1), the only zone where bacterial biomass was clearly bottom-up controlled, as derived from the significant relationships between chl $a$ and bacterial activity (Fig. 5B) and between biomass and production (Fig. 5C). In such areas or periods where bacterial assemblages are predominantly controlled by resources, the abundance and relative contribution of HNA cells could prove a good estimator of bacterial activity and production. However, when bottom-up control was non-existent, such as in the East zone, HNA cell abundance bore no relationship at all with Leu uptake (Fig. 5G). The Central zone would lie in an intermediate situation. There, Leu incorporation rates and chl a were significantly correlated (Fig. 5E), but not bacterial biomass and production (Fig. 5F), yet yielding a weakly significant correlation between HNA cell abundance and activity (Fig. 5D). Sherr et al. (2006) have identified regional, trophic-based differences in the responsiveness of HNA cells to chl a similar to those found here. Although we only investigated here the effect of substrate supply, the type of control (bottom-up or topdown) operating on bacterial communities would then emerge as a critical factor in the potential use of HNA cell abundance as a proxy for activity.

\section{Cell size versus nucleic acid content}

The variability in LNA and HNA bacteria individual biomass estimates (12 to $21 \mathrm{fg} \mathrm{C} \mathrm{cell}^{-1}$ ) is in accordance with previous studies in these shelf waters (Iriberri et al. 1990, Barbosa et al. 2001, Valencia et al. 2003), but considerably lower than that reported by Fukuda et al. (1998). Even so, significantly different values were found in the 3 zones (Table 1). The steady decrease in mean HNA cell biomass as we moved eastwards (Table 1) could be indicative of higher grazing pressure along the west-east gradient, consistent with the hypothesized decrease in bottom-up control. Grazers selectively remove larger and more active cells (e.g. 
González et al. 1990, Sherr et al. 1992, del Giorgio et al. 1996). Vaqué et al. (2001) have demonstrated an increase in grazing rates with increasing HNA abundance in the Mediterranean. According to the model of Pace \& Cole (1994) enhanced grazing on HNA bacteria would uncouple them from resources, i.e. decrease the bottom-up control of bacterial biomass (Fig. 5). In a recent paper, Tadonléké et al. (2005) concluded that grazing by ciliates was a major factor responsible for lack of response of HNA abundance to chl $a$ in a series of lakes. Although mortality by protistan grazers or viral infection was not assessed during the present study, the lower biomass of HNA cells in the East zone could be indicative of a preferential loss of the most active and larger cells within this group. If grazing pressure became stronger, it might even reverse the vertical pattern of \%HNA found here, as suggested by Corzo et al. (2005).

Despite the lack of significant relationships between LNA abundance and activity in this study, some authors have reported on similar substrate assimilation rates of LNA and HNA bacteria (Button \& Robertson 2000, Zubkov et al. 2001, Longnecker et al. 2005), similar responses of both groups to changes in phytoplankton biomass (Sherr et al. 2006) or higher growth rates of LNA bacteria at depth (Scharek \& Latasa 2007). We link these contradictory results to actual bacterial sizes. Considering both groups, mean carbon biomass was highly and positively correlated with the respective activity-abundance correlation coefficient (Fig. 6), implying that only at large sizes might we expect a good correspondence between HNA abundance and bulk activity. Although correlation analysis cannot prove causal relationships, the known effect of bacterial size on activity (Gasol et al. 1995, Servais et al. 1999, Lebaron et al. 2002) may help answer the question: How useful is HNA cell abundance as a proxy of bacterial activity in the sea? It probably depends on their size. Given the usually larger size of bacteria in incubated samples, it is not surprising that HNA cells were consistently responsible for increases in total bacterioplankton activity in laboratory experiments (Gasol et al. 1999, Vaqué et al. 2001), whereas discrepancies appeared only in natural samples (Zubkov et al. 2001, Jochem et al. 2004, Longnecker et al. 2005). In the study region, LNA cells are usually larger than HNA cells in spring (Calvo-Díaz \& Morán 2006). These authors hypothesized that the abundance of LNA bacteria could be better correlated to Leu incorporation rates than HNA cells during periods of higher relative size. This was indeed suggested by the positive correlation of LNA cell abundance with activity in the Central zone, while that of HNA bacteria in the East zone was negative (Fig. 6). In agreement with Lebaron et al. (2002), our analysis suggests that we should consider cell size together with the relative nucleic acid content if we are to rely on flow cytometry-based estimates of bacterial activity in marine ecosystems.

\section{CONCLUSIONS}

The ubiquitous presence of 2 groups of heterotrophic bacteria of differing nucleic acid content in the ocean has boosted the preferential association of HNA cells with the active members of the community. We show that both the absolute abundance and relative contribution of HNA cells were significantly correlated with leucine incorporation rates, but the low percentage of variance explained would question its ready use as a proxy for activity in natural systems. Our analysis suggests that the utility of HNA cell abundance as an activity index is related to the degree of bottom-up regulation of bacteria via their trophic interactions with phytoplankton, with bacterial size also playing a fundamental role. We conclude that only at relatively large bacterial sizes could we expect bacterial activity and production to unequivocally respond to an increase in the abundance of HNA cells. Given the usually smaller size of bacteria in the open ocean relative to coastal waters, future research is needed to determine whether HNA cell abundance is still of potential use as an indicator of activity in oligotrophic ecosystems and to assess the relevance of the proposed and closely related factors (bottom-up control and cell size) in determining the bacterial response.

Acknowledgements. We are grateful to the chief scientist, C. Porteiro, and to the captain and crew of RV 'Thalassa' for their assistance during the cruise. The collaboration of A. Álvarez, P. Estévez, R. Revilla and M. Varela is also appreciated. J. Lorenzo and F. Castiñeira measured chl a concentrations. J. M. Gasol, A. Calvo-Díaz, R. Scharek and Á. López-Urrutia, together with 3 anonymous referees, provided helpful comments on earlier drafts. G. González-Nuevo kindly prepared Fig. $1 \mathrm{~B}$ and $\mathrm{C}$. This research was funded in part by project SARDYN (QLRT-2001-00818) of the European Union and by the special action 'Reconocimiento oceanográfico en la época de la floración primaveral en Galicia y Cantábrico' of the Ministry of Science and Technology (Spain).

\section{LITERATURE CITED}

Alonso-Sáez L, Gasol JM, Arístegui J, Vilas JC, Vaqué D, Duarte CM, Agustí S (2007) Large-scale variability in surface bacterial carbon demand and growth efficiency in the subtropical North East Atlantic Ocean. Limnol Oceanogr 52(2):(in press)

Barbosa AB, Galvao HM, Mendes PA, Alvarez-Salgado XA, Figueiras FG, Joint I (2001) Short-term variability of heterotrophic bacterioplankton during upwelling off the NW Iberian margin. Prog Oceanogr 51:339-359

Billen G, Servais P, Becquevort S (1990) Dynamics of bacterioplankton in oligotrophic and euphotic aquatic environ- 
ments: bottom-up or top-down control? Hydrobiologia 207:37-42

Bode A, Varela M, Canle M, González N (2001) Dissolved and particulate organic nitrogen in shelf waters of northern Spain during spring. Mar Ecol Prog Ser 214:43-54

Bode A, Varela M, Casas B, González N (2002) Intrusions of eastern North Atlantic central waters and phytoplankton in the north and northwestern Iberian shelf during spring. J Mar Syst 36:197-218

Button DK, Robertson B (2000) Effect of nutrient kinetics and cytoarchitecture on bacterioplankter size. Limnol Oceanogr 45:499-505

Calvo-Díaz A, Morán XAG (2006) Seasonal dynamics of picoplankton in shelf waters of the southern Bay of Biscay. Aquat Microb Ecol 42:159-174

Calvo-Díaz A, Morán XAG, Nogueira E, Bode A, Varela M (2004) Picoplankton community structure along the northern Iberian continental margin in late winter-early spring. J Plankton Res 26:1069-1081

Corzo A, Rodríguez-Gálvez S, Lubian L, Sobrino C, Sangrá P, Martínez A (2005) Antarctic marine bacterioplankton subpopulations discriminated by their apparent content of nucleic acids differ in their response to ecological factors. Polar Biol 29:27-39

del Giorgio PA, Bouvier TC (2002) Linking the physiologic and phylogenetic successions in free-living bacterial communities along an estuarine sallinity gradient. Limnol Oceanogr 47:471-486

del Giorgio P, Gasol JM, Vaqué D, Mura P, Agustí S, Duarte CM (1996) Bacterioplankton community structure: protists control net production and the proportion of active bacteria in a coastal marine community. Limnol Oceanogr 41: 1169-1179

Ducklow HW (1992) Factors regulating bottom-up control of bacteria biomass in open ocean plankton communities. Arch Hydrobiol Beih Ergeb Limnol 37:207-217

Dufour P, Torréton JP (1996) Bottom-up and top-down control of bacterioplankton from eutrophic to oligotrophic sites in the tropical northeastern Atlantic Ocean. Deep-Sea Res I 43:1305-1320

Fukuda R, Ogawa H, Nagata T, Koike I (1998) Direct determination of carbon and nitrogen contents of natural bacteria assemblages in marine environments. Appl Environ Microbiol 64:3352-3358

Gasol JM, del Giorgio PA (2000) Using flow cytometry for counting natural planktonic bacteria and understanding the structure of planktonic bacterial communities. Sci Mar 64:197-224

Gasol JM, del Giorgio PA, Massana R, Duarte CM (1995) Active versus inactive bacteria: size-dependence in a coastal marine plankton community. Mar Ecol Prog Ser 128:91-97

Gasol JM, Zweifel UL, Peters F, Fuhrman JA, Hagström ^ (1999) Significance of size and nucleic acid content heterogeneity as measured by flow cytometry in natural planktonic bacteria. Appl Environ Microbiol 65: 4475-4483

Gasol JM, Pedrós-Alió C, Vaqué D (2002) Regulation of bacterial assemblages in oligotrophic plankton systems: results from experimental and empirical approaches. Antonie Leeuwenhoek 81:435-452

González JM, Sherr EB, Sherr BF (1990) Size-selective grazing on bacteria by natural assemblages of estuarine flagellates and ciliates. Appl Environ Microbiol 56:583-589

Iriberri J, Unanue M, Ayo B, Barcina I, Egea L (1990) Attached and free-living dividing bacteria in two aquatic systems. Lett Appl Microbiol 11:87-89
Jellett JF, Li WKW, Dickie PM, Boraie A, Kepkay PE (1996) Metabolic activity of bacterioplankton communities assessed by flow cytometry and single carbon substrate utilization. Mar Ecol Prog Ser 136:213-225

Jochem FJ, Lavrentyev PJ, First MR (2004) Growth and grazing rates of bacteria groups with different apparent DNA content in the Gulf of Mexico. Mar Biol 145: 1213-1225

Kirchman DL (1993) Leucine incorporation as a measure of biomass production by heterotrophic bacteria. In: Kemp PF, Cole JJ, Sherr BF, Sherr EB (eds) Handbook of methods in aquatic microbial ecology. Lewis Publishers, Boca Raton, FL, p 509-512

Lebaron P, Servais P, Agogue H, Courties C, Joux F (2001) Does the high nucleic acid content of individual bacterial cells allow us to discriminate between active cells and inactive cells in aquatic systems? Appl Environ Microbiol 67:1775-1782

Lebaron P, Servais P, Baudoux AC, Bourrain M, Courties C, Parthuisot N (2002) Variations of bacterial-specific activity with cell size and nucleic acid content assessed by flow cytometry. Aquat Microb Ecol 28:131-140

Li WKW, Jellett JF, Dickie PM (1995) DNA distributions in planktonic bacteria stained with TOTO or TO-PRO. Limnol Oceanogr 40:1485-1495

Li WKW, Head EJH, Harrison WG (2004) Macroecological limits of heterotrophic bacterial abundance in the ocean. Deep-Sea Res I 51:1529-1540

Longnecker K, Sherr BF, Sherr EB (2005) Activity and phylogenetic diversity of bacterial cells with high and low nucleic acid content and electron transport system activity in an upwelling ecosystem. Appl Environ Microbiol 71: 7737-7749

Marie D, Vaulot D, Partensky F (1996) Application of the novel nucleic acid dyes YOYO-1, YO-PRO-1, and PicoGreen for flow cytometric analysis of marine prokaryotes. Appl Environ Microbiol 62:1649-1655

Marie D, Partensky F, Jacquet S, Vaulot D (1997) Enumeration and cell cycle analysis of natural populations of marine picoplankton by flow cytometry using the nucleic acid stain SYBR Green I. Appl Environ Microbiol 63: 186-193

Moran MD (2003) Arguments for rejecting the sequential Bonferroni in ecological studies. Oikos 100:403-405

Morán XAG, Massana R, Gasol JM (2001) Light conditions affect the measurement of oceanic bacterial production via leucine uptake. Appl Environ Microbiol 67: 3795-3801

Morán XAG, Estrada M, Gasol JM, Pedrós-Alió C (2002a) Dissolved primary production and the strength of phytoplankton bacterioplankton coupling in contrasting marine regions. Microb Ecol 44:217-223

Morán XAG, Gasol JM, Pedrós-Alió C, Estrada M (2002b) Partitioning of phytoplanktonic organic carbon production and bacterial production along a coastal-offshore gradient in the NE Atlantic during different hydrographic regimes. Aquat Microb Ecol 29:239-252

Morán XAG, Fernández E, Pérez V (2004) Size-fractionated primary production, bacterial production and net community production in subtropical and tropical domains of the oligotrophic NE Atlantic in autumn. Mar Ecol Prog Ser 274:17-29

Neveux J, Lantoine F (1993) Spectrofluorometric assay of chlorophylls and pheopigments using the least-squares approximation technique. Deep-Sea Res I 40:1747-1765

Norland S (1993) The relationship between biomass and volume of bacteria. In: Kemp PF, Sherr BF, Sherr EB, Cole JJ 
(eds) Handbook of methods in aquatic microbial ecology. Lewis Publishers, Boca Raton, FL, p 303-307

Oliver JL, Barber RT, Smith WO, Ducklow HW (2004) The heterotrophic bacterial response during the Southern Ocean Iron Experiment (SOFeX). Limnol Oceanogr 49: 2129-2140

Pace ML, Cole JJ (1994) Comparative and experimental approaches to top-down and bottom-up regulation of bacteria. Microb Ecol 28:181-193

Pace ML, Cole JJ (1996) Regulation of bacteria by sources and predation tested in whole-lake experiments. Limnol Oceanogr 41:1448-1460

Richardson AJ, Schoeman DS (2004) Climate impact on plankton ecosystems in the Northeast Atlantic. Science 305:1609-1612

Scharek R, Latasa M (2007) Growth, grazing and carbon flux of high and low nucleic acid bacteria differ in surface and deep chlorophyll maximum layers in the NW Mediterranean Sea. Aquat Microb Ecol 46:153-161

Servais P, Courties C, Lebaron P, Troussellier M (1999) Coupling bacterial activity measurements with cell sorting by flow cytometry. Microb Ecol 38:180-189

Servais P, Casamayor EO, Courties C, Catala P, Parthuisot N, Lebaron P (2003) Activity and diversity of bacterial cells with high and low nucleic acid content. Aquat Microb Ecol 33:41-51

Seymour JR, Seuront L, Mitchell JG (2005) Microscale and small-scale temporal dynamics of a coastal planktonic microbial community. Mar Ecol Prog Ser 300:21-37

Sherr BF, Sherr EB, Mcdaniel J (1992) Effect of protistan grazing on the frequency of dividing cells in bacterioplankton assemblages. Appl Environ Microbiol 58:2381-2385

Sherr BF, del Giorgio P, Sherr EB (1999) Estimating abundance and single-cell characteristics of respiring bacteria via the redox dye CTC. Aquat Microb Ecol 18:117-131

Sherr EB, Sherr BF, Longnecker K (2006) Distribution of bacterial abundance and cell-specific nucleic acid content in the Northeast Pacific Ocean. Deep-Sea Res I 53:713-725

Sieracki ME, Viles CL (1992) Distributions and fluorochromestaining properties of submicrometer particles and bacteria in the North-Atlantic. Deep-Sea Res I 39:1919-1929

Šimek K, Hornák K, Jezbera J, Mašin M, Nedoma J, Gasol

Editorial responsibility: Josep Gasol,

Barcelona, Spain
JM, Schauer M (2005) Influence of top-down and bottomup manipulations on the R-BT065 subcluster of betaproteobacteria, an abundant group in bacterioplankton of a freshwater reservoir. Appl Environ Microbiol 71: 2381-2390

Simon M, Azam F (1989) Protein content and protein synthesis rates of planktonic marine bacteria. Mar Ecol Prog Ser 51:201-213

Smith EM, del Giorgio PA (2003) Low fractions of active bacteria in natural aquatic communities? Aquat Microb Ecol 31:203-208

Tadonléké RD, Planas D, Lucotte A (2005) Microbial food webs in boreal humic lakes and reservoirs: ciliates as a major factor related to the dynamics of the most active bacteria. Microb Ecol 49:325-341

Troussellier M, Courties C, Lebaron P, Servais P (1999) Flow cytometric discrimination of bacterial populations in seawater based on SYTO 13 staining of nucleic acids. FEMS Microbiol Ecol 29:319-330

Valencia J, Abalde J, Bode A, Cid A and 5 others (2003) Variations in planktonic bacterial biomass and production, and phytoplankton blooms off A Coruña (NW Spain). Sci Mar 67:143-157

Vaqué D, Casamayor EO, Gasol JM (2001) Dynamics of whole community bacterial production and grazing losses in seawater incubations as related to the changes in the proportions of bacteria with different DNA content. Aquat Microb Ecol 25:163-177

Wetz MS, Wheeler PA (2004) Response of bacteria to simulated upwelling phytoplankton blooms. Mar Ecol Prog Ser 272:49-57

Worm B, Myers RA (2003) Meta-analysis of cod-shrimp interactions reveals top-down control in oceanic food webs. Ecology 84:162-173

Zubkov MV, Fuchs BM, Burkill PH, Amann R (2001) Comparison of cellular and biomass specific activities of dominant bacterioplankton groups in stratified waters of the Celtic Sea. Appl Environ Microbiol 67:5210-5218

Zubkov MV, Allen JI, Fuchs BM (2004) Coexistence of dominant groups in marine bacterioplankton community-a combination of experimental and modelling approaches. J Mar Biol Assoc UK 84:519-529

Submitted: August 18, 2006; Accepted: November 13, 2006 Proofs received from author(s): January 22, 2007 